\title{
足関節障害に対する関節鏡の有用性について
}

\author{
対馬いづはら病院整形外科 \\ 鳥越 雄 史・小田純 爾 \\ 西口雅 彦·矢 野 勝 巳
}

\section{Arthroscopy for Ankle Joint Trauma}

\author{
Takafumi Torigoshi, Junji Oda, Masahiko Nishiguchi \\ and Katsumi Yano \\ Department of Orthopaedic Surgery, \\ Tsushima Izuhara Hospital, \\ Nagasaki, Japan
}

\begin{abstract}
We treated 15 cases of ankle joint trauma with arthroscope. Patients ranged in age from 13 to 63 years, with a mean of 36.2 years. They comprised of 3 with osteochondritis dissecans of the talus, 2 with ligamennt injuries, 2 with old avulsion fractures of the lateral malleolus, and 8 with malleolar fractures. Osteochondritis dissecans of the talus were treated with fragement excisios, curettage and transmalleolar or percutaneous drilling of the crater.

No complications were seen in all cases such as neurological and arterial damage. Ankle arthroscopy is useful in the diagnosis and treatment of ankle joint trauma.

Key words : Ankle Arthroscopy（足関節鏡）, Arthroscopic surgery（鏡視下手術）, osteochondritis dissecans of the talus (距骨離断性軟骨炎), Ankle fracture (足関節 骨折）
\end{abstract}

$$
\text { はじめに }
$$

足関節鏡は比較的侵襲が少なく, 病変部の直接の確 認や処置が可能であることで, 近年盛んに行われるよ うになった，今回我々が施行した足関節鏡症例につい て若干の考察を加え報告する。

\section{対象及び方法}

対象は 1997 年より当院で足関節鏡施行した 15 例 15 関節（男性 9 例，女性 6 例）で，年齢は 13 から 63 歳, 平均 36.2 歳である. 対象疾患は距骨離断性骨軟 骨炎及び骨軟骨骨折 3 例, 足関節勒帯損傷 2 例, 陳旧 性外果剥離骨折 2 例，足関節骨折 8 例である.

手術は 3 例において全身麻酔, 残りは腰椎麻酔下に 行った，体位は全例仰臥位で抑制带による徒手牟引下 に前脛骨筋内側の関節裂隙における前内側刺入点，第
3 腓骨筋腱の外側の関節裂隙における前外側刺入点を 用い, 径 $2.7 \mathrm{~mm}$ の直視鏡・30 度斜視鏡にて鏡視を 行った.

今回足関節鏡を行った目的は，X 線像で診断でき ない軟骨病変を主に検索・評価し，いかに低侵襲で治 療を行うかにある。すなわち脛距関節・遠位脛腓関節・ 外側距果関節の軟骨損傷の有無, 関節内遊離体の有無, 滑膜の性状, 離断性軟骨炎例では骨片の可動性の有無, 足関節骨折例では骨折部の整復状態等を調べ診断及び 治療に役立てた。

$$
\text { 結果 }
$$

離断性骨軟骨炎及び骨軟骨骨折は 3 例で, 内果骨切 り行うことなく低侵襲に病変部の可動性の有無や処置 を行うため鏡視下手術を行った．3例ともに前方アプ ローチのみで病巣の確認は十分で, 鏡視下に病巣怪爬 · 
ドリリングが可能であった.

足関節靫带損傷は 2 例で, 䩲帯損傷の直接の確認よ りも関節内損傷の有無を調べるために鏡視を行った. 実際に靶帯断裂部の直接の確認はできなかったが，関 節包の断裂が見られ䩲帯断裂を思わせた．関節軟骨損 傷例は認めなかった。

陳旧性外果剥離骨折は 2 例で，骨片の鏡視下摘出及 び関節内合併損傷の有無の確認のために鏡視を行った. 骨片を確認できたが，2例ともに軟部組織への付着が 強く鏡視下に摘出できず観血的に摘出を行った．関節 内には滑膜の増殖認めるも，軟骨損傷やメニスコイド
等の合併は認めなかった。

足関節骨折は 8 例で骨折の整復状態, 軟骨損傷の有 無の確認のために鏡視を行い，3例に脛骨側に軟骨損 傷を認め, 内 1 例は関節内遊離体を認め鏡視下に摘出 を行った。また 2 例にメニスコイドの合併を認めた。

全例ともに神経・血管損傷, 感染等の合併症を生じ た例はなかった。

症

例

症例 1（図 1,2，3）: 14 歳, 男性. 左距骨離断性 骨軟骨炎. 以前より数回の左足関節捻挫の既往あり.
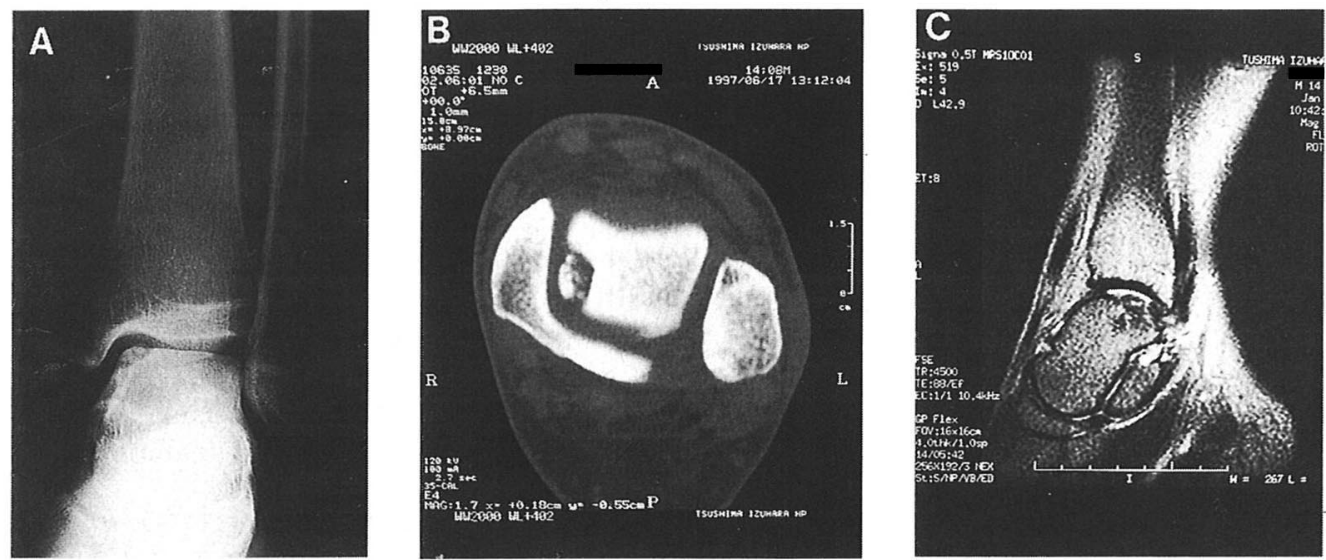

図 1 症例 14 歳男性

A：初診時 X 線像. 左距骨滑車内側に骨透亮像を認める.

$\mathrm{B}$ ：初診時 CT. 同部に離断した軟骨片を認める.

C : 初診時 MRI. T2 強調像にて軟骨片周囲に低信号域を認めた.
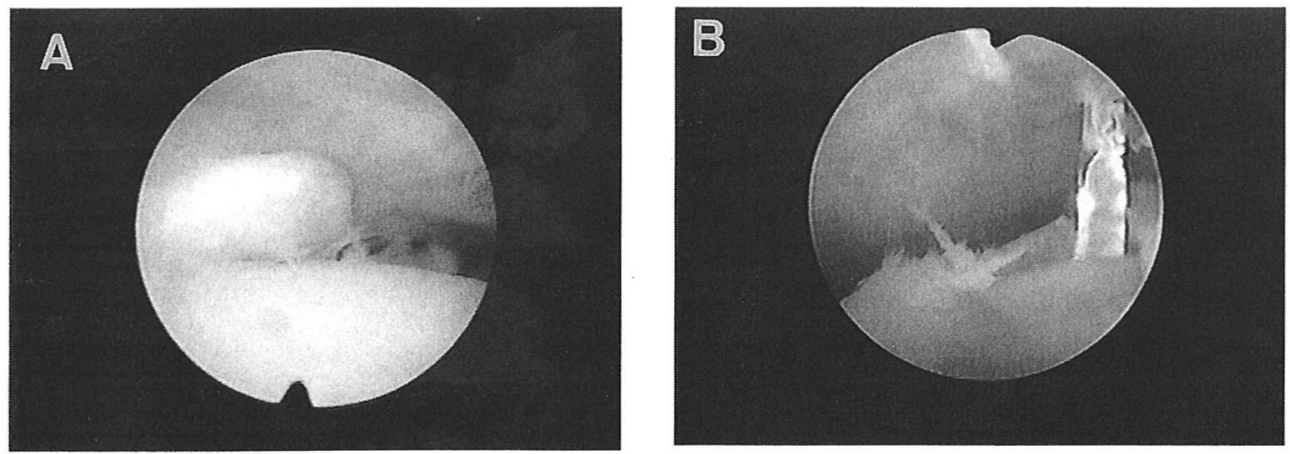

図 2 関節鏡所見.

A : 距骨滑車内側に軟骨片の離断を認め鏡視下に摘出を行った，

$\mathrm{B}$ : 径 $1.8 \mathrm{~mm}$ のキルシュナー・ワイヤーを用い経内果的に 4 カ所ドリリングを行った. 

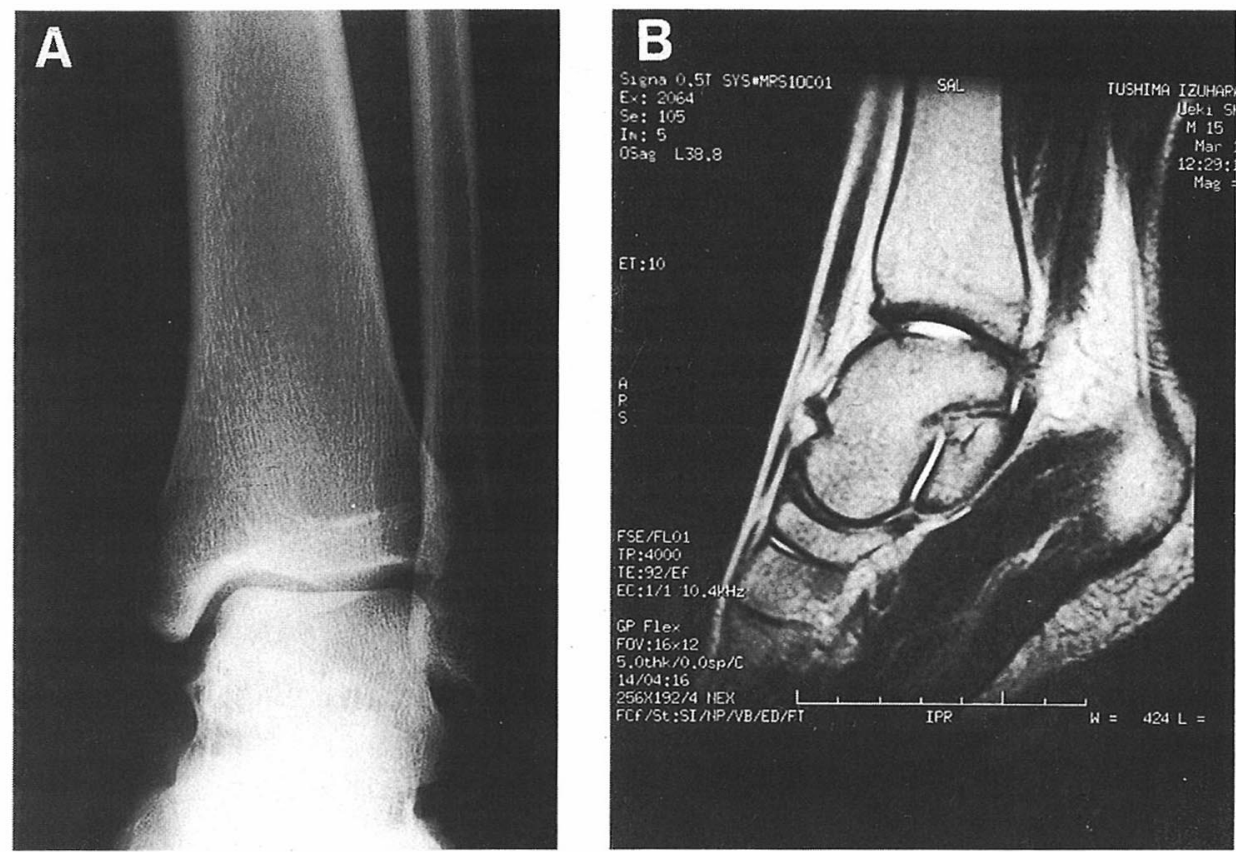

図 $3 \mathrm{~A}$ : 術後6 カ月の X 線像. 距骨滑車内側の骨透亮像は消失した.

B : 術後6カ月の MRI. T2 強調像における低信号域は消失した.
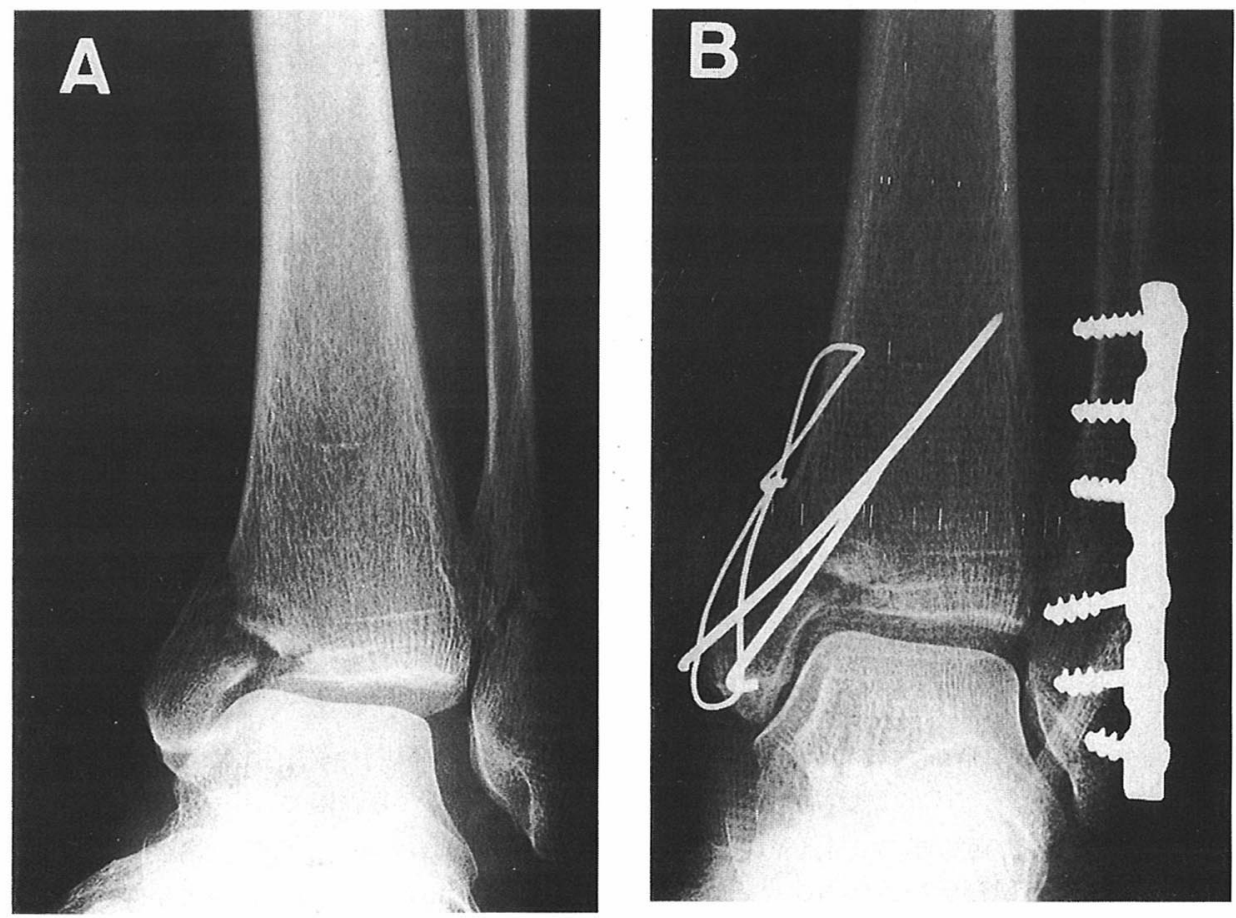

図 4 症例 263 歳女性

A : 受傷時 X 線像. Lauge-Hansen 分類 PA stage 3 の左足関節雨果骨折を認めた.

$\mathrm{B}$ ：外果にリコンストラクション・プレート, 内果に引き寄せ締結法を用い骨接合を行った. 

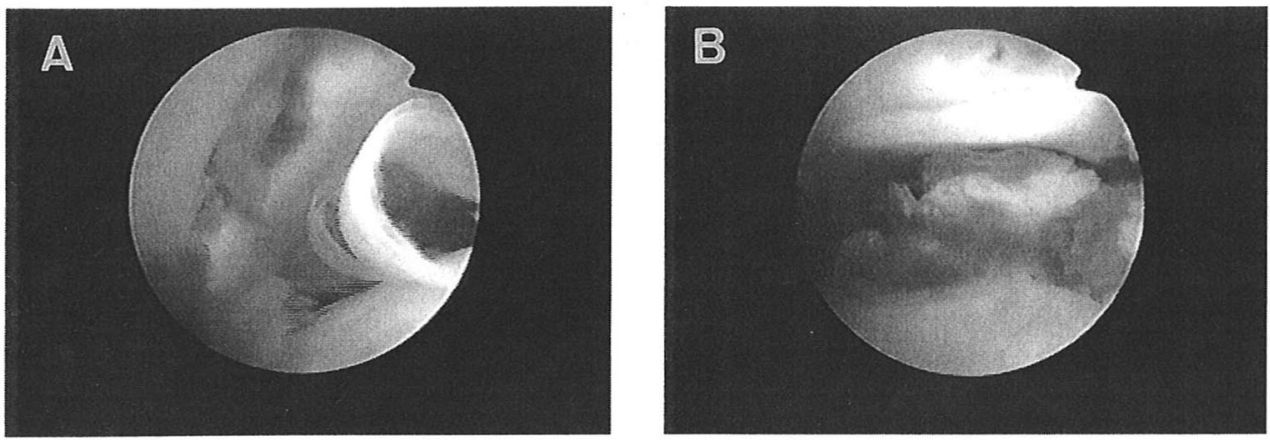

図 5 関節鏡所見

A：内果骨折部を親きあげる.

B：関節内に遊離軟骨片を認摬視下に摘出を行った。

平成 9 年 6 月 17 日左足関節痛を主訴に来院。X 線像 で左距骨滑車内側に骨透亮像を認める。CTにおいて 同部に離断した軟骨片を認め，またMRIでは軟骨片 周囲に低信号域を認めた，左距骨離断性骨軟骨炎の診 断にて 7 月 17 日全身麻酔下に関節鏡視下ドリリング を施行する，術中の関節鏡所見では距骨滑車内側に軟 骨片の離断を認め，同部を摘出後径 $1.8 \mathrm{~mm}$ のキルシュ ナー・ワイヤーを用い経内果的に 4 カ所ドリリングを 行った。術後 3 週間目で部分荷重を開始した。術後 6 カ月の X 線像で距骨滑車内側の骨透亮像は消失し, MRIにおいて軟骨片周囲の低信号域が消失した。現 在左足関節可動域制限はなく, 疼痛も改善している。 症例 2（図 4，5）: 63 歳，女性. 左足関節両果骨折. 平成 10 年 1 月 15 日下腿に電柱が当たり受傷。X 線 像上 Lauge-Hansen 分類 PA stage 3 の左足関節両 果骨折を認める。また右下腿骨折を合併していた１ 月 25 日全身麻酔下に外果にリコンストラクション。 プレート，内果に引き寄せ締結法を用い骨接合術を行っ た，骨接合施行後に関節鏡視を行い，関節内に遊離し た軟骨片を認め鏡視下に摘出を行った。

\section{考察}

足関節鏡に関する報告は Burman ${ }^{11}$ が屍体を用い 行ったが，関節裂隙が狭いため鏡視には向かないと述 べている。本邦においては 1939 年の高木 ${ }^{10)}$ の報告に 始まり，その後渡辺式 24 号関節鏡の開発 ${ }^{12)} に よ り$ 臨 床応用がなされるようになった。

足関節は滕や肩関節と比較して関節裂隙が狭いため
関節鏡の適応は限られている．現在我々は関節内遊離 体の摘出, 足関節骨折の整復状態の確認, 離断性軟骨 炎等の軟骨病変の診断と治療，足関節靶帯損傷を主な 適応としている，その他に最近では鏡視下足関節固定 術の報告も見受けられる ${ }^{3 / 6999}$. 一方その禁忌として高 度な変形性関節症，創部感染等があげられる。

鏡視下手術の利点の一つとして，X 線像で写らな い軟骨片などの関節内遊離体を直接確認・除去できる ことがあげられる，足関節外傷後明らかな X 線像異 常を認めないのに疼痛を訴える例を認めるが，このよ うな例では軟骨損傷や軟部組織損傷を合併しているこ とが考えられる. Wolin ら ${ }^{13}$ が足関節捻挫後のメ二 スコイドについて報告した後，メニスコイドについて の報告が多く見られるが2987 足関節鏡を行うことによ り，これらを確認・除去ができるようになった。我々 も特に足関節䩲带損傷例では勒帯の状態を見ると言う ょりも,メニスコイドの有無や，軟骨損傷の有無を確 認するのを主眼に鏡視を行っている.

他の利点として手術侵襲が少なく，早期からの運動 が可能であることがあげられる，特に離断性骨軟骨炎 例では骨切りを行うことなく，直接に病巣の確認や処 置が可能であり，このことにより術後の固定期間を短 縮できるという点では有用である。離断性軟骨炎例に 対する鏡視下手術に関する報告を近年多く認め, 中で は Herbert screw や PDS pin を用いた骨接合術も 報告されている11)。しかし我々の症例では病巣掻爬 · ドリリングのみで良好な成績が得られている。長谷川

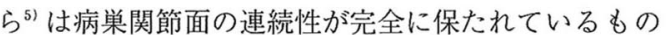


で，病巣部が周囲より隆起を示すものに対しては骨り 固定を行うべきだと述べている。

また足関節骨折例では関節面の整復状態を確認でき るのみではなく，関節内遊離骨片の有無の確認及び除 去ができるという利点がある。実際に我々の例でも 8 例中 1 例に遊離骨片を認めており，これが術後の疼痛 の原因の一つになるものと考えた。

関節鏡の合併症として関節裂隙が狭いため関節軟骨 を損傷しやすい，関節鏡刺入時に神経血管系を損傷す ることがあるなどがあげられる．Ferkelら"は 518 例中 $10 \%$ に浅腓骨神経や腓腹神経などの損傷を認め たと報告している。今回の我々の症例では特に合併症 を認めた例はなかった。

問題点として十分な毫引を行わないと, 手術器具の 関節内操作が困難なことがあげら机る。衰引法として 踵骨への直達率引，創外固定器，弾力包带，軟性装 具”などを用いた方法が報告されているが，我々は侵 襲が少なく行える方法として抑制帯を用いるようにし ている。他の問題点として鏡視範囲の狭さがあげら机 る. Ferkel ら は前内. 外側, 後内・外側アプロー チを用いることで十分な鏡視範囲が得られると述べて いる. しかし後方アプローチでは神経血管系損傷り危 険性が高いことまた，今回我々が経験した症例では前 方アプローチのみで鏡視可能であったことにより，後 カアプローチを用いることはなかった。

\section{ま と め}

(1)足関節障害をきたした 15 例 15 関節に対し足関節 鏡を施行した。

(2)手術侵襲が少なく特に離断性骨軟骨炎例では早期 からの運動が可能であった。
(3) X 線像で診断できない関節内病変の直接の確認 や処置に有用であった。

(4)術後神経血管損傷や感染等の合併症を生じた例は なかった。

\section{参 考 文 献}

1) Burman, M.S.: Arthroscopy or the direct visualization of joint. J. Bone and Joint Surg., 13:669-695, 1931

2) David, F.M. et al.: Arthroscopic treatment of chronic synovitis of the ankle. Arthroscopy, 5:110114, 1989.

3) Dent, C. M.: Arthroscopic ankle arthrodesis. J. Bone and Joint Surg., 75-B : 830-832, 1993.

4) Ferkel, R.D.: Arthroscopy of the ankle and foot. J. Bone and Joint Surg., 75-A : 1233-1242, 1993.

5）重谷川惊ほか：距骨消車離断性:骨軟情炎に対す万镜视 下手術の経験，関節鏡，21：123-128, 1996.

6）神戸克明ほか：鏡視下足関節固定術の小経騃。関節鏡, $22: 87-91,1997$.

7）熊井司ほか：足関節鏡に対する軟性綔引引装具の使闸. 別冊整形外科, $30: 175-177,1996$.

8) McCarroll, J.R. et al.: Meniscoid lesion of the ankle in soccer players. Am. J. Sports Med., 15: 255-257, 1987.

9) Ogilvie-Harris, D.J.: Arthroscopically assisted arthrodesis for osteoarthrotic ankle. J. Bone and Joint Surg., 75-A : 1167-1174, 1993.

10）高林憲次：関節鏡。日整会誌， $14: 359-384,1939$.

11）土屋明弘ほか：距骨離断性:骨軟骨炎に対する関節鏡視 下骨接合術。関節鏡, $19: 189-193,1994$.

12）渡辺间:毅：関節鏡の現洸と将来。外科治療，26：73$77,1972$.

13) Wolin, L. et al.: Internal derangement of the talofibular component of the ankle. Surg. Gynecol Obstet, $91: 193-200,1950$ 